\title{
Going Global - A Methodology for Shaping Students for the Global Workplace
}

\author{
Raymond E. Thompson, Ronald Sterkenburg \\ Purdue University
}

\begin{abstract}
Many programs are seeking ways to become 'global'. What does that really mean? How does a program become 'global' in nature? The Aviation Technology (AT) department at Purdue University is seeking the answers to those questions. Often, coursework in diversity or foreign language is suggested as a way to become global. The AT department felt that a more basic approach was needed to understand what it meant to be global. What traits make someone 'global'? How is a program shaped to produce students for whom a global perspective is second nature? Should we be trying to make students global? In response, a committee of faculty and industrial members were gathered in June 2000 to begin answering those questions.

The group began by discussing what globalization meant to the industrial members. From these discussions, a Vision Goal emerged and four subset areas of further study were identified: Business Relationships, Technical, Education - Business and Cultural, and Regulatory. Next, a process for obtaining information from a number of locales pertinent to these subsets was laid out. First, a needs assessment of the aviation industry personnel would be conducted.

Observation, survey, and interview methods are anticipated being used. A visitation template will be created to ensure consistent results. Second, structured visits to obtain the assessment information. Third, involve the AT Industrial Advisory Committee in a parallel process to provide input and feedback on suggested curriculum changes. Fourth, develop methods meeting the identified needs and working them into the academic curriculum.

Development of a visitation template and visitation areas is in progress. Grants and air carrier partners will provide travel support. Once the visits are completed, a specific set of performance objectives will be determined. Then, the AT department can provide curriculum and other opportunities for students to become global.
\end{abstract}

\section{Introduction}

"Going Global" is a popular term in both academia and industry today. What does that mean? Traditionally it has meant offering international study opportunities for students and faculty exchange. While this is still true, developing a program that is "global" entails much more than that. Feedback from the Aviation Technology Industrial Advisory Committee ${ }^{1}$ (ATIAC) indicates that they want students who are able to operate in the global marketplace. This includes understanding the world aerospace market, cultural differences, international rules and regulations, foreign government processes, foreign business practices, and foreign language. The ATIAC realizes that while producing a student competent in all those areas is unrealistic, 
students need exposure to them and understand that these are all factors that must be taken into account to be successful in the international business arena.

Study Abroad programs are still an important component in instilling global awareness into a student. However additional opportunities specific to aviation need developed. Internship and research opportunities can be important components. Additionally, identifying methods that bring global awareness into the classroom every day may be even more critical. As with any new venture, the first step is to identify the skills and traits desired in students who have a global perspective. In Aviation Technology, this began in May 2000 with the formation of the Global Initiative Committee ${ }^{2}$ to identify these areas. Next, the preliminary findings of this group were presented to the ATIAC in October 2000 for discussion, feedback, and refinement. Beginning in January 2001, travel to identified aviation programs in foreign locations will begin to establish specific opportunities for students. These visits will be completed by fall 2001 and the program for globalization for study abroad, internships, research, and in-house activities will be finalized during the 2001-2002 academic year. It is anticipated that the first students will enter the program in May 2002.

\section{Global Initiative Committee}

In May 2000 a group of AT faculty and industrial representatives met as the Global Initiative Committee. This group initially consisted of five faculty members and two industrial partner members representing the manufacturing and service components of the air transport industry. The group began by discussing and defining what globalization meant and what traits and skills students should acquire. The industrial members both are affiliated with companies that are global in scope. Discussion centered about what they look for in an employee they send to an international location. After several meetings ${ }^{3}$, a series of major areas and sub-topics were identified as the issues that students needed to be aware of. Table 1 displays these areas and subtopics.

This information was conveyed to the ATIAC in October 2000. Overall the industrial advisory board agreed with the preliminary topics. Somewhat surprisingly, considerable controversy arose over the issue of foreign language. The group was split almost in half regarding the need for understanding a second language. In addition, the split also tended to be associated with job category. The industrial members representing commercial piloting felt that a second language was not beneficial considering that English is the official language of aviation worldwide. Members representing the administrative, technical, and manufacturing disciplines strongly encouraged taking a second language. Further discussion appeared to indicate that of all the disciplines, commercial piloting tended to has the most restricted interaction with personnel located at international stations. This may account for the opinions expressed.

The ATIAC strongly endorsed development of aviation specific study abroad opportunities and international internships. Industrial members agreed to provide contact information at their international locations for the visitation teams. 
Table 1: Desired Student Skill Areas and Associated Traits

\begin{tabular}{|c|c|c|c|}
\hline $\begin{array}{c}\text { Business } \\
\text { Relationships }\end{array}$ & Technical & $\begin{array}{c}\text { Education - Business \& } \\
\text { Cultural }\end{array}$ & Regulatory \\
\hline $\begin{array}{l}\text { - } \begin{array}{l}\text { Develop a global } \\
\text { mindset }\end{array} \\
\text { - } \begin{array}{l}\text { Understand global } \\
\text { business drivers }\end{array} \\
\text { - } \begin{array}{l}\text { Placement of } \\
\text { graduates into } \\
\text { global companies }\end{array}\end{array}$ & $\begin{array}{l}\text { Understand } \\
\text { the "values" } \\
\text { of aviation }\end{array}$ & $\begin{array}{l}\text { Transfer knowledge of } \\
\text { diversity issues } \\
\text { Increase sensitivity, } \\
\text { concern, and issue } \\
\text { awareness } \\
\text { On and Off-campus } \\
\text { opportunities for } \\
\text { diverse cultural } \\
\text { immersion } \\
\text { Prepare students and } \\
\text { faculty to interact } \\
\text { globally } \\
\text { Integrate electronic } \\
\text { commerce, } \\
\text { communication, and } \\
\text { training }\end{array}$ & $\begin{array}{l}\text { Understand and } \\
\text { compare the } \\
\text { education and } \\
\text { certification } \\
\text { systems for North } \\
\text { America, Canada, } \\
\text { and Europe. }\end{array}$ \\
\hline
\end{tabular}

III. Information Gathering

Thorough background research is necessary before embarking on a globalization program. As with most schools, resources are a concern and unnecessary duplication of effort should be avoided. Therefore we have split the information gathering process into two distinct activities. Phase I is investigating what globalization activities are taking place within other departments at Purdue University and what agreements and programs already pre-exist within the International Studies Office on campus. In addition, we are researching the Internet to find equivalent aviation programs worldwide. Most of the programs already established tend to be focused in non-technical areas. Part of our research is to identify programs that relate to aviation in schools that already have agreements with Purdue. The main initial search parameters include curriculum compatibility, language barriers, cultural differences and educational facilities. Initially, our main focus is those universities and colleges in English speaking countries or universities that offer an English spoken degree program. We have some promising opportunities with Universities and Colleges in Australia, the United Kingdom and the Netherlands. Ultimately we plan to have contacts in all major geographic areas of the globe.

Phase II consists of in-situ visits to several of these programs. An issue of high importance is that students participating at any of the selected programs receive a high quality, comparable experience. To ensure that the resources utilized for such visits are effective, the visitation teams will use a template. These teams will consist of faculty and industrial advisors who will visit the selected educational institutions. There will be a set of questions, objectives and expectations that will have to be addressed and completed by the teams. The teams will interview students, faculty and people living in the surrounding areas of the university. They will conduct surveys of the student population and observe lectures and laboratory activities. Data will also be 
collected regarding living conditions in the dormitories or housing facilities. If the students don't like the university it will be very difficult to motivate students to spend a semester at this particular location. The important aspect of the template is to gather data that can be analyzed and compared to similar data gathered by other teams. In essence, the group will function in a similar fashion to an accreditation team visit. An additional function of the teams will be to explore contacts with aerospace industries in the countries selected for study abroad programs. The intent is to develop internship and research programs in which students can participate while they are studying abroad.

In December 2000, the Aviation Technology department received a $\$ 24,000$ grant to support travel-related expenses and matching support in the form of air travel from one of the department's industrial partners. Thus we plan to make at least four visitations in the spring and summer of 2001 and analyze the information in the fall of 2001. After all visits are completed and the data analyzed, we will involve our Industrial Advisory Committee in October/November 2001 to provide input and feedback to develop a specific set of performance objectives. The summer of 2002 has been targeted as the first opportunity for students to participate in challenging studying abroad programs.

\section{Developing Global Programs}

The information gathering via research and visitations will be the foundation for the development of a department-wide global initiative. The goal is for all aviation students to increase their level of awareness of aviation, business, and relationships beyond what occurs in the United States. The envisioned program contains several components. The base component is to develop activities, both in and out of the classroom, that take place in residence so every student can participate. These may include course work and assignments that study aviation issues and cultures on a global level rather than domestic. Purdue University has a significant international student body. Activities that require students to become involved with the international student population, global fairs, and cultural events are being discussed. These activities are such that all students can be exposed with a minimum use of resources.

The visitation data will provide the information needed to structure study abroad activities and internships that take place internationally. Once the visitation data is analyzed, specific schools and programs can be targeted and agreements established. Student cost will be an issue for these activities. Although efforts will be made to keep costs at a minimum and subsidize, not all students will be able to participate. This provides additional incentives to develop as many inhouse activities as possible.

Identification of specific programs and activities will take place after the visitation data is collected. However the data collection process, funding, ATIAC, and Global Initiative Committee frameworks are already in place. Obviously there are general programs in place at Purdue in which students can participate. However it is the opinion of the Aviation Technology department that our students can be better served with programs specifically developed for a technical major. 


\section{Summary}

Aviation, along with many industries, has become truly global in nature. Aviation in particular requires a degree of international and inter-company cooperation and communication that is unprecedented. Students need to be prepared to enter this marketplace by having experienced and learned about the global nature of this industry before entering the marketplace. To accomplish this, the Aviation Technology department has embarked on the development of a global program that will provide every AT student with a minimal experience in global affairs and additional opportunities for students able and willing to participate. The foundation for this program will be a series of embedded activities in courses and extra-curricular activities that all students will participate in. Additionally, students will be able to participate in study abroad and internship opportunities as well. The key to this program is development. Although programs currently exist at Purdue University, these tend to be general in nature. The AT department would prefer to develop opportunities more specific to the aviation industry.

To this end, the department formed the Global Initiative Committee, which began by studying what "going global" means to Aviation Technology. This was followed by input from the ATIAC. Next, faculty from Aviation Technology will concurrently study what is currently available at Purdue, and perform a series of visitations to a number of internationally situated institutions to establish study abroad programs that are aviation based. At the same time, the visitation teams will work with industry members to establish internship and applied research opportunities for AT students. The visitation data will be gathered and a comprehensive program, in which every student will participate to a minimal level, will be established. Student participation will begin in May 2002.

The end goal is for all AT students to think globally first and domestically second. The programs and activities under development hope to accomplish that. If successful, we will send students into the workplace who are ready to work anywhere the global economy takes them.

Bibliography

1. Industrial Advisory Committee. Meeting Minutes Dated October $27^{\text {th }}, 2000$. West Lafayette.

2. Global Initiative Committee. Meeting Minutes May $15^{\text {th }}, 2000$. West Lafayette.

3. Global Initiative Committee. Meeting Minutes June $6^{\text {th }}, 2000$. Indianapolis.

\section{RAYMOND E. THOMPSON}

Raymond E. Thompson is Associate Professor of Aviation Technology at Purdue University in West Lafayette. Prof. Thompson founded the AOT Advanced Composite Laboratory and coordinates student services within the department. His current research includes assessment, technology in the classroom, distance education, and aviation human factors.

RONALD STERKENBURG

Ronald Sterkenburg is Assistant Professor of Aviation Technology at Purdue University in West Lafayette. Prof. Sterkenburg is developing freshman programs in materials technology and coordinating the development of globalization information for the department. 